\title{
Comparative assessment of dexterity tests results using two internationally recognized scales in patients with cerebral palsy, users of medical textiles
}

\author{
DOI: 10.35530/IT.071.04.20205
}

\section{ABSTRACT - REZUMAT}

Comparative assessment of dexterity tests results using two internationally recognized scales in patients with cerebral palsy, users of medical textiles

The recent studies report an increase in the percentage of newborns diagnosed with cerebral palsy $(C P)$ in industrialized countries due to the increased survival rate of infants with low birth weight. The assessment of the upper limb motor function and manual skills are important steps in achieving a suitable multi-modal therapeutical plan, aiming at gaining functional independence and early integration into society. The study seeks to identify how the motor deficiency present at the level of the upper limbs influences the manual skills of CP patients reflected in daily activities (Activities of Daily Living $-A D L)$ and using medical textiles. 35 patients diagnosed with $C P$ were assessed during hospitalization using, for the comparative reflection of $A D L$ dexterity assessment results, at the same patient, quantified, the Action Research Arm Test (ARAT) scale and ABILHAND-Kids. A highly significant correlation was found, the ABILHAND-Kids score being moderately correlated with the ARAT score, obtained in the upper limb with more deficient functionality (0.578) and respectively with better functionality (0.570). The assessment of the child suffering of CP, using the ABILHAND-Kids questionnaire and the ARAT test provides to the rehabilitation team useful information, with the benefit of complementarity for the elaboration, based on several correlated elements, of the case management plan and methodology. Proper treatment, instituted early, can have a favorable influence on the social integration of these people. A remarkable contribution has been made by the textile domain which, through its sustained concerns regarding the research and development of biotechnologies and biomaterials, proves its permanent concern in supporting and integrating these people.

Keywords: upper limb motor function, manual skills/dexterity, day-to-day activities, upper limb motricity disorders, social inclusion

Evaluarea comparativă a rezultatelor testelor de dexteritate utilizând două scale recunoscute la nivel internațional la pacienți cu paralizie cerebrală, utilizatori de textile medicale

Studii recente raportează o creștere a procentului de nou-născuți diagnosticați cu paralizie cerebrală (PC) în țările industrializate datorită creșterii ratei de supraviețuire a sugarilor cu greutate scăzută la naștere. Evaluarea funcției motorii a membrelor superioare și a abilităților manuale sunt pași importanți în realizarea unui plan terapeutic multimodal adecvat, care vizează obținerea independenței funcționale și integrarea timpurie în societate. Prezentul studiu urmărește să identifice modul în care deficiența motorie prezentă la nivelul membrelor superioare influențează abilitățile manuale ale pacienților cu PC reflectate în activitățile zilnice (ADL) și de utilizare a textilelor medicale. 35 de pacienți diagnosticați cu PC au fost evaluați în timpul spitalizării folosind, pentru reflectarea comparativă a rezultatelor evaluării dexterității în ADL, la același pacient, cuantificat, scala de testare Action Research Arm Test (ARAT) și ABILHAND-Kids. S-a găsit o corelație extrem de semnificativă, scorul ABILHAND-Kids fiind moderat corelat cu scorul ARAT, obținut la nivelul membrului superior cu funcționalitate mai deficitară $(0,578)$ și, respectiv, cu o funcționalitate mai bună $(0,570)$. Evaluarea copilului care suferă de PC, folosind chestionarul ABILHAND-Kids și testul ARAT, oferă echipei de recuperare informații utile, cu beneficiul complementarității pentru elaborarea, pe baza mai multor elemente corelate, a planului și metodologiei de gestionare a cazurilor. Tratamentul adecvat, instituit precoce, poate avea o influență favorabilă asupra integrării sociale a acestor persoane. O contribuție remarcabilă o are domeniul textil care, prin preocupările susținute în ceea ce privește cercetarea și dezvoltarea biotehnologiilor și biomaterialelor, dovedește preocuparea permanentă în susținerea și integrarea acestor persoane.

Cuvinte cheie: funcția motorie a membrului superior, abilități manuale/dexteritate, activități cotidiene, tulburări de motricitate la nivelul membrului superior, incluziune socială

\section{INTRODUCTION}

$\mathrm{CP}$ is a group of posture and movement disorders caused by nonprogressive lesions of the central nervous system under development stage [1]. The CP occurs to an average of 1.5-2.5/1000 of newborns [2], of which over $2 / 3$ have mobility difficulties at the level of the upper limb. Recent studies mention the existence of over 17 million patients diagnosed with CP worldwide, of which $39 \%$ are hemiplegic, $38 \%$ diplegic and $23 \%$ tetraplegic [3].

From a clinical point of view, the spastic form prevails - present in $70-80 \%$ of the cases - followed by the 
dyskinetic form - in 10-20\% of the cases - and respectively, the ataxic and mixed forms [4].

Proper treatment, instituted early, can have a favorable influence on the social integration of these people. A remarkable contribution has been made by the textile domain which, through its sustained concerns regarding the research and development of biotechnologies and biomaterials, proves its permanent concern in supporting and integrating these people.

\section{MATERIAL AND METHODS}

In this study, 35 patients diagnosed with CP were assessed during hospitalization at Centrul National Clinic de Recuperare Neuropsihomotorie pentru Copii "Dr. Nicolae Robanescu" (CNCRNC) between September 2018 and February 2019 using, for the comparative reflection of ADL dexterity assessment results, at the same patient, quantified, the Action Research Arm Test scale (ARAT) and ABILHANDKids. The selection of cases for setting up the study group had as criteria for inclusion/exclusion the patients' age and, respectively, their level of cooperation as well as the degree of muscle hypertonia in the shoulder, elbow, fist and fingers. The statistical processing of primary data was performed with the Statistical Package for the Social Sciences SPSS Statistics 24 program.

From our knowledge, ARAT is not a scale currently used for functional assessment of CP children. To shed light on this, we have preliminarily developed an afferent literature review by interrogating the Medline/PubMed [5], PMC [6], Elsevier [7], PEDro [8], ISI Web of Knowledge/Science [9] databases, according to the identification paradigm based on the following keywords: "Action Research Arm Test", "Action Research Arm Test Cerebral Palsy", "ARAT", "ARAT Cerebral Palsy". The search results, after removing redundancies, are shown in table 1.

Considering the above finding, we hope to contribute through this study to the extension of the assessment tools used in the CP with the older but validated (for strokes) ARAT scale [10-11].

The study has been approved by the Ethics Committee of the CNCRNC under no. 9586/15.12. 2017 and was carried out at CNCRNC headquarters. The group of patients enrolled in the study has the following characteristics:

- Age ranging from 6 to 18 years;
- Symmetric gender distribution (randomly occurring): $50 \%$ girls, $50 \%$ boys;

$-37 \%$ diplegic patients, $33 \%$ tetraplegic patients, $30 \%$ hemiplegic patients;

- Spasticity in upper limb mAS < 3;

$-60 \%$ of them had a form of neuropsychomotor developmental delay compatible, however, with an acceptable level of cooperation during the abovementioned assessments.

According to the literature data, the discriminative threshold was located at an Intelligence Quotient (IQ) $=55$ [12].

The patients were tested for the assessment of manual skills and motor deficit of the upper limb in terms of ADL type tasks provided in the ABILHAND-Kids questionnaire portfolio and respectively the motor deficit, quantified by the ARAT scale [13].

The ABILHAND-Kids test is focused on the perception of the assessed child's parents regarding his/her ability to perform certain activities. The questionnaire was developed using the Rasch Measurement Model [14], which provides a method of converting gross scores to a linear measure situated on a one-dimensional scale. The ABILHAND-Kids test has been specially designed for assessing the skills of children with CP. Specialty literature mentions a high reliability $(R=0.94)$ and good reproducibility over time $(R=$ 0.91 ) of this test [15].

The questionnaire [16] contains 21 elements which are designed to estimate how difficult or easy it is for the child to perform the daily tasks without support (even if in the everyday life he/she is supported), regardless of the hand the child uses and regardless of the adopted strategy.

ARAT assesses the motor deficit in the upper limb by measuring the patient's ability to handle objects of different shapes and weights. It is divided into 4 subtests, which, based on 19 elements, assess the Gross Arm Movement, the poly-digito-palmar grasp/prehension (Grasp), the grip/cylindrical clamp (Grip), and the pinch/ two-digit clamp (Pinch).

The studies show an internal consistency of ARAT calculated using the Cronbach Alpha coefficient ( $\alpha=$ 0.98 ) and a reproducibility expressed by a value of "intraclass correlation" coefficients ICCs $=0.97$ excellent, respectively 0.92 inter- and 0.97 intra-observational [17].

For performing the comparative analysis, we first performed the qualitative analogies of functionality

THE NUMERICAL RESULTS OF DATABASES SEARCH AFTER ELIMINATION OF REDUNDANCIES

\begin{tabular}{|l|c|c|c|c|c|c|}
\hline \multicolumn{1}{|c|}{ Keywords } & PubMed & PMC & PEDro & Elsevier & ISI & Total \\
\hline "Action Research Arm Test" & 0 & 19 & 0 & 0 & 0 & 19 \\
\hline "Action Research Arm Test Cerebral Palsy" & 5 & 0 & 0 & 0 & 0 & 5 \\
\hline "ARAT" & 0 & 38 & 0 & 0 & 0 & 38 \\
\hline "ARAT Cerebral Palsy" & 1 & 0 & 0 & 0 & 0 & 1 \\
\hline Total & 6 & 57 & 0 & 0 & 0 & 63 \\
\hline
\end{tabular}




\begin{tabular}{|c|c|c|c|c|}
\hline \multicolumn{5}{|c|}{$\begin{array}{l}\text { QUALITATIVE ANALOGIES OF FUNCTIONALITY BETWEEN THE ELEMENTS QUANTIZED THROUGH } \\
\text { THE ABILHAND-KIDS AND ARAT SCALES }\end{array}$} \\
\hline \multirow{2}{*}{ ABILHAND-Kids } & \multicolumn{4}{|c|}{ ARAT } \\
\hline & Grasp & Grip & Pinch & Gross movement \\
\hline Opening a jar of jam & $\mathrm{X}$ & & & \\
\hline Putting on a backpack & & & & $\mathrm{X}$ \\
\hline Opening a toothpaste tube & & & $\mathrm{X}$ & \\
\hline Opening the package of a chocolate bar & & & $\mathrm{X}$ & \\
\hline Washing the upper body & & & & $x$ \\
\hline Rolling the sleeves of a sweater & & & $\mathrm{X}$ & \\
\hline Sharpening a pencil & & $\mathrm{X}$ & & \\
\hline Taking off a T-shirt & & & & $\mathrm{X}$ \\
\hline Squeezing toothpaste on the toothbrush & & & $\mathrm{X}$ & \\
\hline Opening a bread box/bag & & & $\mathrm{X}$ & \\
\hline Unscrewing a bottle cap & & $\mathrm{X}$ & & \\
\hline Zipping up pants & & & $X$ & \\
\hline Buttoning up a shirt & & & $\mathrm{X}$ & \\
\hline Filling a glass of water & & $\mathrm{X}$ & & \\
\hline Turning on a desk lamp & & & $\mathrm{X}$ & \\
\hline Putting on a hat & & & & $x$ \\
\hline Buckling a jacket & & $\mathrm{X}$ & & \\
\hline Unbuttoning pants & & & $\mathrm{X}$ & \\
\hline Opening a bag of chips & & & $\mathrm{x}$ & \\
\hline Zipping up a jacket & & & $x$ & \\
\hline Removing a coin from a wallet & & & $X$ & \\
\hline
\end{tabular}

between the quantified elements through the two scales, according to table 2 .

Thus, the study aimed at the correlative/comparative analysis after compatibilization of the adequate primary data from the tests performed with the two above-mentioned scales.

The primary data from the assessment of the ADL type activities were collected by means of the questionnaire ABILHAND-Kids, and are shown for each patient, through the responses to the 21 questions, the possible response variants being: impossible (score 0 ), difficult (score 1) and easy (score=2). The data obtained were analyzed using the Rasch model of conversion of raw scores to a linear scale. The manual skills expressed in logits were calculated for a conversion interval of $95 \%$ and they represent the ABILHAND-Kids score. This was analyzed, using the statistical processing IBM SPSS 24 program, in relation to the score ARAT obtained by summing the scores of the four subtests - the gross arm movement (GM), the poly-digito-palmar prehension (PP), the cylindrical clamp (CC) and the two-digit clamp (TDC) - both for upper limb with better functionality (ULBF) and for upper limb with deficient functionality (ULDF). The processed primary data input is presented in table 3.

\section{RESULTS}

The correlation results are shown in table 4.

Results:

- All the correlations are highly significant (significance < 0.001).

- The ABILHAND score is correlated with the ULBF score (0.570), only a little more with the ULDF score $(0.578)$, and some more with the total score (0.622).

\section{DISCUSSIONS}

To our knowledge, the ARAT test has not been used in CP cases assessments, which also results from the afferent literature review elaborated. We consider it useful to employ the association approach in assessing the functionality of the upper limb, especially with regard to manual ability/dexterity, using in each case both a questionnaire (therefore a tool based on parents' responses) and the effective, objective measurement of several motor control parameters.

\section{CONCLUSION}

The results of this study are a premise for the future use of both the ABILHAND-Kids questionnaire and the ARAT test, in the field of pediatric neurorehabilitation, for assessing patients with cerebral palsy. 


\begin{tabular}{|c|c|c|c|c|c|c|c|c|c|c|c|}
\hline \multicolumn{12}{|c|}{ PRIMARY DATA } \\
\hline Patient ID & $\begin{array}{l}\text { Patient } \\
\text { measure }\end{array}$ & $\begin{array}{l}\text { ULBF } \\
\text { PP_I }\end{array}$ & $\begin{array}{l}\text { ULBF } \\
\text { CC_I }\end{array}$ & $\begin{array}{l}\text { ULBF } \\
\text { _TDC_I }\end{array}$ & $\begin{array}{l}\text { ULBF } \\
\text { GM_I }\end{array}$ & $\begin{array}{l}\text { ULDF } \\
\text { PP_I }\end{array}$ & $\begin{array}{l}\text { ULDF } \\
\text { CC_I }\end{array}$ & $\begin{array}{l}\text { ULDF } \\
\text { _TDC_I }\end{array}$ & $\begin{array}{l}\text { ULDF } \\
\text { GM_I }\end{array}$ & $\begin{array}{l}\text { ULBF } \\
\text { sum }\end{array}$ & $\begin{array}{l}\text { ULDF } \\
\text { sum }\end{array}$ \\
\hline patient 1 & 4.066 & 17 & 12 & 18 & 9 & 14 & 12 & 18 & 7 & 56 & 51 \\
\hline patient 2 & 5.043 & 18 & 12 & 18 & 9 & 18 & 11 & 18 & 9 & 57 & 56 \\
\hline patient 3 & -3.542 & 18 & 8 & 14 & 8 & 10 & 4 & 12 & 6 & 48 & 32 \\
\hline patient 4 & -0.697 & 16 & 10 & 13 & 9 & 17 & 9 & 12 & 9 & 48 & 47 \\
\hline patient 5 & 6.684 & 18 & 12 & 18 & 9 & 18 & 9 & 18 & 9 & 57 & 54 \\
\hline patient 6 & 6.649 & 18 & 12 & 15 & 9 & 18 & 12 & 17 & 9 & 54 & 56 \\
\hline patient 7 & 1.763 & 6 & 4 & 4 & 7 & 0 & 0 & 0 & 0 & 21 & 0 \\
\hline patient 8 & -3.177 & 10 & 0 & 0 & 6 & 10 & 0 & 0 & 0 & 16 & 10 \\
\hline patient 9 & 2.549 & 17 & 9 & 17 & 9 & 17 & 9 & 15 & 9 & 52 & 50 \\
\hline patient 10 & 2.155 & 13 & 6 & 12 & 7 & 12 & 4 & 12 & 7 & 38 & 35 \\
\hline patient 11 & 0.075 & 18 & 12 & 18 & 9 & 0 & 0 & 0 & 3 & 57 & 3 \\
\hline patient 12 & -0.611 & 17 & 7 & 13 & 8 & 12 & 7 & 12 & 9 & 45 & 40 \\
\hline patient 13 & 3.83 & 18 & 12 & 18 & 9 & 17 & 12 & 18 & 9 & 57 & 56 \\
\hline patient 14 & 0.964 & 18 & 8 & 18 & 9 & 18 & 7 & 11 & 9 & 53 & 45 \\
\hline patient 15 & 0.656 & 18 & 9 & 17 & 9 & 18 & 10 & 15 & 9 & 53 & 52 \\
\hline patient 16 & 6.601 & 18 & 12 & 18 & 9 & 18 & 12 & 18 & 9 & 57 & 57 \\
\hline patient 17 & 3.852 & 18 & 11 & 17 & 9 & 18 & 12 & 17 & 9 & 55 & 56 \\
\hline patient 18 & 6.684 & 18 & 11 & 18 & 9 & 18 & 11 & 17 & 9 & 56 & 55 \\
\hline patient 19 & 1.854 & 17 & 11 & 18 & 0 & 11 & 4 & 6 & 0 & 46 & 21 \\
\hline patient 20 & 3.116 & 18 & 11 & 18 & 9 & 4 & 4 & 0 & 6 & 56 & 14 \\
\hline patient 21 & 4.381 & 18 & 12 & 18 & 9 & 16 & 10 & 16 & 9 & 57 & 51 \\
\hline patient 22 & -1.748 & 15 & 8 & 14 & 9 & 14 & 8 & 8 & 7 & 46 & 37 \\
\hline patient 23 & 6.684 & 18 & 12 & 18 & 9 & 18 & 12 & 18 & 9 & 57 & 57 \\
\hline patient 24 & - & 18 & 12 & 18 & 9 & 18 & 12 & 18 & 9 & 57 & 57 \\
\hline patient 25 & 6.684 & 18 & 12 & 18 & 9 & 18 & 8 & 18 & 9 & 57 & 53 \\
\hline patient 26 & 1.571 & 18 & 11 & 16 & 9 & 18 & 11 & 15 & 9 & 54 & 53 \\
\hline patient 27 & 5.043 & 18 & 12 & 18 & 9 & 18 & 12 & 18 & 9 & 57 & 57 \\
\hline patient 28 & 3.9 & 18 & 12 & 18 & 9 & 18 & 12 & 18 & 9 & 57 & 57 \\
\hline patient 29 & 3.844 & 18 & 11 & 18 & 9 & 18 & 11 & 18 & 9 & 56 & 56 \\
\hline patient 30 & 6.684 & 18 & 12 & 18 & 9 & 15 & 11 & 15 & 9 & 57 & 50 \\
\hline patient 31 & 0.902 & 15 & 8 & 8 & 9 & 10 & 4 & 4 & 8 & 40 & 26 \\
\hline patient 32 & 4.381 & 18 & 12 & 18 & 9 & 18 & 11 & 18 & 9 & 57 & 56 \\
\hline patient 33 & 2.768 & 18 & 12 & 18 & 9 & 17 & 9 & 12 & 7 & 57 & 45 \\
\hline patient 34 & 0.569 & 18 & 12 & 17 & 9 & 15 & 12 & 14 & 9 & 56 & 50 \\
\hline patient 35 & 1.056 & 17 & 8 & 15 & 9 & 14 & 8 & 12 & 9 & 49 & 43 \\
\hline
\end{tabular}

Table 4

\begin{tabular}{|c|l|c|c|c|c|}
\hline \multicolumn{7}{|c|}{ THE CORRELATION RESULTS } \\
\hline \multirow{2}{*}{ Scores } & \multicolumn{1}{|c|}{ Variables } & ABILHAND score & ULBF score & ULDF score & Total score (ULBF+ULDF) \\
\hline \multirow{4}{*}{ ABILHAND score } & Pearson Correlation & 1 & 0.570 & 0.578 & 0.622 \\
\cline { 2 - 6 } & Sig. (2-tailed) & - & 0.000 & 0.000 & 0.000 \\
\cline { 2 - 6 } & $\mathrm{N}$ & 35 & 34 & 34 & 34 \\
\hline \multirow{4}{*}{ ULBF score } & Pearson Correlation & 0.570 & 1 & 0.693 & 0.872 \\
\cline { 2 - 6 } & Sig. (2-tailed) & 0.000 & - & 0.000 & 0.000 \\
\cline { 2 - 6 } & $\mathrm{N}$ & 34 & 35 & 35 & 35 \\
\hline \multirow{4}{*}{ ULDF score } & Pearson Correlation & 0.578 & 0.693 & 1 & 0.957 \\
\cline { 2 - 6 } & Sig. (2-tailed) & 0.000 & 0.000 & - & 0.000 \\
\cline { 2 - 6 } & $\mathrm{N}$ & 34 & 35 & 35 & 35 \\
\hline \multirow{3}{*}{$\begin{array}{l}\text { Total score } \\
\text { (ULBF+ULDF) }\end{array}$} & Pearson Correlation & 0.622 & 0.872 & 0.957 & - \\
\cline { 2 - 6 } & Sig. (2-tailed) & 0.000 & 0.000 & 0.000 & 35 \\
\cline { 2 - 6 } & $\mathrm{N}$ & 34 & 35 & 35 & \\
\hline
\end{tabular}

Note: The correlation is significant at the 0.01 level (2-tailed). 


\section{CONFLICT OF INTEREST}

The authors declare that there are no conflicts of interest in this work.

\section{AUTHORS CONTRIBUTION}

All the authors have contributed equally to the achievement of this work and have approved for its publication.

\section{ACKNOWLEDGEMENT}

The main author thanks to all the co-authors for their excellent collaboration and support in their PhD student activity, the present study being linked to the whole of the $\mathrm{PhD}$ work: "Researches on integrated modes for the development of digital and preparatory abilities for writing, for children with cerebral palsy". This research was supported financially by the project CNFIS-FDI-2018-0582 - Supporting Excellence Research within The Bucharest University of Economic Studies in the context of the principles of sustainable development and open research. 6. Supporting field research excellence in universities Beneficiary: The Bucharest University of Economic Studies.

\section{REFERENCES}

[1] Onose, G., Padure, L., Compendiu de neuroreabilitare la adulţi, copii şi vârstnici, Ed. Universitară "Carol Davila", Bucharest, 2008

[2] Garfunkel, L.C., Kaczorowski, J.M., Christy, C., Pediatric Clinical Advisor, 2007

[3] McGillivray, A., General Movements Screening Guideline Women and Babies: General Movements Assessments (GMA) and other assessment modalities for prediction of cerebral palsy and adverse early neurodevelopment in high-risk infants, 2011

[4] Avramescu, E.T., Roşulescu, E., Zăvăleanu, M., Călina, M., Enescu, D., Kinetoterapia în afecțiuni pediatrice, Ed. Universitaria, Craiova, 2007

[5] US National Library of Medicine National Institutes of Health, Available at: https://www.ncbi.nlm.nih.gov/pubmed/ [Accesed March 2020]

[6] PMC, Available at: https://www.ncbi.nlm.nih.gov/pmc/ [Accesed March 2020]

[7] Elsevier, Available at: https://www.elsevier.com [Accesed March 2020]

[8] Physiotherapy Evidence Database, Available at: https://www.pedro.org.axu [Accesed March 2020]

[9] Web of Science, Available at: https://apps.webofknowledge.com [Accesed March 2020]

[10] Yozbatiran, N., Der-Yeghiaian, L., Cramer, S.C., A standardized approach to performing the action research arm test, In: Neurorehabil. Neural Repair, 2008

[11] Muresanu, D.F., et al., Cerebrolysin and Recovery After Stroke (CARS): A randomized, placebo-controlled, double-blind, multicenter trial, In: Stroke, 2016

[12] Cherry, K., How Low IQ Scores Are Determined, 2020, Available at: https://www.verywellmind.com/what-isconsidered-a-low-iq-2795282 [Accesed March 2020]

[13] Action Research Arm Test, Available at : http://www.strokecenter.org/wp-content/uploads/2011/08/action_research arm test.pdf [Accesed March 2020]

[14] Rasch Measurement Model, Available at: http://rssandbox.iescagilly.be/rasch-measurement-model.html [Accesed March 2020]

[15] Arnould, C., Penta, M., Renders, A., Thonnard, J.L., ABILHAND-Kids: A measure of manual ability in children with cerebral palsy, In: Neurology, 2004

[16] ABILHAND-Kids specific to cerebral palsy children, Available at: http://rssandbox.iescagilly.be/abilhand-kidsdownloads.html\#abilhand-kids-specific-to-cerebral-palsy-children [Accesed March 2020]

[17] Nijland, R., Van Wegen, E., Verbunt, J., Van Wijk, R., Van Kordelaar, J., Kwakkel, G., A comparison of two validated tests for upper limb function after stroke: The wolf motor function test and the action research arm test, In: J. Rehabil. Med., 2010

\section{Authors:}

\section{CORINA SPOREA ${ }^{1}$, MARGARETA STELA FLORESCU ${ }^{2}$, DUMITRU FERECHIDE ${ }^{3}$, IOAN CRISTESCU $^{4}$}

${ }^{1}$ Centrul Național Clinic de Recuperare Neuropsihomotorie pentru Copii „Doctor Nicolae Robănescu”, Soldat Dumitru Mincă Street, no. 44, 041408, Bucharest, Romania

${ }^{2}$ Bucharest University of Economic Studies, Faculty of Public Administration and Management,

Piata Romana, no. 6, 010374, Bucharest, Romania

e-mail: margareta.florescu@ari.ase.ro

${ }^{3}$ Carol Davila University of Medicine and Pharmacy, Eroii Sanitari Boulevard, no. 8, Bucharest, Romania e-mail: dferec@yahoo.com

${ }^{4}$ Bucharest Emergency Hospital, Calea Floreasca, no. 8, 014461, Bucharest, Romania e-mail: ioancristescu@yahoo.com

Corresponding author:

CORINA SPOREA

e-mail: corina.sporea@gmail.com 